\title{
HUBUNGAN ANTARA PENGUNGKAPAN-DIRI DAN KEPUASAN PERNIKAHAN DENGAN DIMEDIASI OLEH INTIMASI
}

\author{
Arif Romdhon \\ Hepi Wahyuningsih \\ Fakultas Psikologi dan Ilmu Sosial Budaya Universitas Islam Indonesia Yogyakarta \\ Email: cukuparif@gmail.com
}

\begin{abstract}
The present study was aimed to examine the relationship between self-disclosure and marital satisfaction, and whether the relation between self-disclosure and marital satisfaction meditated by intimacy. The participants of study involved 110 individual married peoples in Cilegon, Banten. As predicted, the result showed that self-disclosure was positively related to marital satisfaction. Furthermore, the result also showed that intimacy was mediator the relationship between selfdisclosure and marital satisfaction. Implications and directions for future research were discussed.
\end{abstract}

Keyword: Self-disclosure, intimacy, Marital Satisfaction.

\begin{abstract}
Abstrak
Penelitian ini bertujuan untuk mengetahui apakah ada hubungan positif antara pengungkapan-diri dan kepuasan pernikahan dan apakah hubungan positif antara pengungkapan-diri dan kepuasan pernikahan tersebut dimediasi oleh intimasi. Penelitian ini melibatkan 110 individu yang sudah menikah di kota Cilegon, Banten. Sebagaimana yang diprediksi, hasil penelitian menunjukan bahwa pengungkapan-diri berhubungan positif dengan kepuasan pernikahan. Selain itu, hasil penelitian juga menunjukkan bahwa intimasi merupakan mediator dalam hubungan antara pengungkapan-diri dan kepuasan pernikahan. Implikasi dan arahan untuk penelitian mendatang juga didiskuasikan dalam tulisan ini.
\end{abstract}

Kata Kunci: Pengungkapan-diri, Intimasi, Kepuasan Pernikahan.

$\mathrm{M}$ enikah merupakan salah satu fitrah yang dimiliki manusia sebagaimana Allah telah menjadikan manusia sebagai makhluk yang berpasangan. Cherlin (Sanders, 2010) menyebutkan bahwa hampir $90 \%$ individu melangsungkan pernikahan, setidaknya sekali dalam seumur hidup. Dalam teori psikososial, Erikson menjelaskan bahwa kompetensi yang harus diraih ketika individu memasuki tahap perkembangan di masa dewasa awal adalah menjalin hubungan dekat dan intimasi (Hall \& Lindzey, 1993), dan menikah merupakan manifestasi dari tugas perkembangan tersebut (Cook, 2001).

Setiap orang yang menikah pasti mengharapkan dan mengidamkan pernikahan yang membahagiakan dan memuaskan. Secara umum, pernikahan sendiri didefinisikan sebagai ikatan jangka panjang yang memiliki kekuatan sosial dan melibatkan kerjasama ekonomi, 
sosial, dan reproduksi antara pasangan (Regan, 2011). Pernikahan juga digambarkan sebagai kebersamaan, percintaan, pemberian dukungan, pemenuhan kebutuhan seksual, dan komitmen seumur hidup (Fincham \& Beach, 2006).

Namun ironisnya, tidak semua individu bisa merasakan kebahagiaan dan kepuasan dalam pernikahannya. Data Direktorat Jenderal Badan Peradilan Agama Mahkamah Agung (Ditjen Badilag MA) menunjukkan bahwa pada kurun 2010, di Indonesia terdapat 285.184 perkara yang berakhir dengan perceraian, atau sekitar $10 \%$ dari angka pernikahan. Angka perceraian tersebut merupakan angka tertinggi sejak 5 tahun terakhir (Saputra, 2011).

Kepuasan dalam sebuah hubungan memiliki peranan untuk menjaga suatu hubungan agar tetap berlangsung dengan baik. Dalam pendekatan model investasi sebuah hubungan, ketidakpuasan rumah tangga dapat menjadi pemicu keretakan dalam bentuk menurunnya level komitmen, yang pada tahap selanjutnya, level komitmen ini akan menentukan stabilitas (berlanjutnya) atau disolusi (berakhirnya) sebuah pernikahan (Rusbult dkk, 1998; Impett dkk, 2001). Oleh karena itu, kepuasan hubungan dapat membantu dalam memberikan sebuah penjelasan mengapa seorang pria atau wanita memilih seseorang menjadi pasangannya dibanding individu lainnya, atau mengapa sebuah pasangan berpisah. Hasil reviu Rodrigues dkk. (2006) menyebutkan bahwa kepuasan pernikahan merupakan salah satu variabel yang berhubungan positif dengan stabilitas pernikahan dan berhubungan negatif dengan disolusi pernikahan. Dengan kata lain, kepuasan terhadap sebuah hubungan merupakan sebuah barometer sekaligus indikator bahwa sebuah hubungan berfungsi dengan baik, memiliki cinta, memberikan kepuasan pada individu yang terlibat di dalamnya, dan juga menentukan resiko terhadap perpisahan (Downing, 2008).

Selain memiliki peran yang penting dalam sebuah hubungan, kepuasan pernikahan juga memiliki peran yang lebih luas terkait dengan kesehatan mental dan kehidupan individu. Wanita dengan kepuasan yang tinggi cenderung memiliki gejala depresi yang rendah (Fincham dkk, 1997). Selain itu, hasil penelitian meta analisis menunjukkan bahwa kepuasan pernikahan memiliki korelasi positif dengan kesejahteraan dan kepuasan hidup (Proulx dkk, 2007). Hasil penelitian Ng dkk (2008) menunjukkan bahwa kepuasan pernikahan memberikan sumbangan $12,2 \%$ terhadap kepuasan hidup individu, setelah mengontrol umur, tingkat pendidikan, dan gender pada orang Cina Malaysia. Berbagai hasil penelitian ini menunjukan bahwa penilaian individu terhadap kepuasan pernikahan, pada gilirannya akan mengambil tempat dan berkembang ke dalam konteks kekeluargaan dan sosial yang lebih besar (Weiss, 2005). Dengan melihat berbagai urgensi dan peran penting kepuasan pernikahan dalam sebuah rumah tangga dan kehidupan seseorang, maka penelitian ini akan memfokuskan pada topik kepuasan pernikahan.

Kepuasan pernikahan didefinisikan sebagai evaluasi subjektif seseorang terhadap hubungan pernikahannya (Reis \& Sprecher, 2009). Banyak penelitian yang dilakukan beberapa dekade terakhir yang berusaha menggali topik ini (Chung, 1990; Bradbury dkk, 2000; Fincham \& Beach, 2010). Berbagai hasil penelitian tersebut menunjukkan bahwa kepuasan pernikahan merupakan topik yang kompleks dan ditentukan oleh banyak faktor. Di antara faktor-faktor tersebut adalah komunikasi, dukungan pasangan, karakteristik individu, dan isu-isu kontekstual (Hess, 2008). Plechaty (Oluwole, 2008) menyebutkan bahwa kepribadian pasangan dan kondisi 
kehidupan pasangan dalam hal tingkat intimasi dan komunikasi, dapat dikatakan sebagai sumber paling sering yang menyebabkan kepuasan atau ketidakpuasan dalam hubungan.

Keterampilan individu dalam berkomunikasi diklaim sebagai kunci dan sumber kehidupan sebuah hubungan yang sukses. Komunikasi yang baik dapat menjadi pembeda antara pasangan yang puas dengan pasangan yang tidak puas terhadap hubungannya (Troy, 2000), dan termasuk di dalam isu komunikasi ini adalah pengungkapan-diri (Green dkk, 2006).

Pengungkapan-diri (self-disclosure) merupakan salah satu keterampilan komunikasi yang penting bagi individu ketika berhubungan dan menjalin interaksi dengan individu lainnya. Menurut Baumeister dan Vohs (2007), pengungkapan-diri mengacu pada proses pembukaan informasi yang bersifat pribadi tentang diri sendiri kepada orang lain. Lebih lanjut Baumeister dan Vohs (2007) menjelaskan, pengungkapan-diri merupakan cara seseorang untuk mengekspresikan perasaannya tentang situasi, untuk menyampaikan pikiran dan pendapatnya tentang suatu topik, untuk mendapatkan kepastian tentang perasaannya, atau untuk mendapatkan suatu saran atau nasihat. Berdasarkan penjelasan tersebut, penelitian ini akan mengkaji lebih jauh mengenai pengungkapan-diri dalam sebuah hubungan pernikahan.

Pengungkapan-diri merupakan salah satu faktor yang memengaruhi kepuasan pernikahan. Pada pasangan yang sudah menikah, skor pengungkapan-diri individu merupakan sebuah prediktor yang signifikan terhadap kepuasan pernikahannya (Hendrick, 1981), baik pada suami maupun istri (Hansen \& Schuldt, 1984). Melalui pengungkapandiri, seseorang bisa menyampaikan berbagai keluhan maupun keberatannya terhadap suatu hal yang dipandang mengganggu dalam sebuah pernikahan. $\mathrm{Hal}$ ini akan membantunya dalam melepaskan ketegangan (tension) dalam dirinya. Dari berbagai penjelasan di atas, maka pertanyaan pertama dari penelitian ini adalah apakah ada hubungan positif antara pengungkapan-diri dan kepuasan pernikahan.

Cozby (Schaefer \& Olson, 1981) menyebutkan bahwa hubungan antara pengungkapan-diri dan kepuasan pernikahan boleh jadi berbentuk garis lengkung (curvilinier). Artinya, ada sebuah titik di mana ketika pengungkapan-diri meningkat, maka kepuasan pernikahan akan cenderung menurun. Dengan demikian, peneliti menduga bahwa pengungkapan-diri dapat menjadi prediktor terhadap kepuasan pernikahan, jika dalam proses interaksi tersebut dimediasi oleh intimasi. Dengan kata lain, ketika seseorang mengungkapkan diri kepada pasangannya, lalu dalam interaksi tersebut tidak memunculkan intimasi, maka hasilnya pengungkapan diri tidak lagi memengaruhi kepuasan pernikahan.

Sternberg (1997) menyebutkan bahwa intimasi merujuk pada perasaan kedekatan, keterhubungan, dan keterikatan dalam mencintai hubungan. Penelitian terdahulu (Waring \& Chelune, 1983; Laurenceau dkk,1998; Laurenceau dkk, 2005) menunjukkan bahwa pengungkapan-diri merupakan prediktor yang signifikan terhadap intimasi. Pengungkapan-diri merupakan bagian proses penting dalam menjalin interaksi yang intim (intimate interactions) dan membangun hubungan intim (intimate relationships), namun intimasi dan pengungkapan-diri bukanlah konstruk yang sinonim (Laurenceau dkk, 2004). Penelitian lain tentang intimasi menunjukan bahwa intimasi memiliki korelasi yang positif dengan kepuasan pernikahan (Rotenberg dkk, 1993; Van 
den Broucke dkk, 1995a; Harper dkk, 2000). Dengan demikian, pertanyaan kedua dari penelitian ini adalah apakah hubungan antara pengungkapan diri dengan kepuasan pernikahan ini dimediasi oleh intimasi.

Berdasarkan berbagai uraian tersebut, peneliti menetapkan dua tujuan dalam penelitian ini. Pertama, untuk membuktikan hubungan positif antara pengungkapan-diri dan kepuasan pernikahan. Kedua, untuk membuktikan bahwa hubungan positif antara pengungkapan diri dan kepuasan pernikahan dimediasi oleh intimasi. Sementara hipotesis dalam penelitian ini, pertama terdapat hubungan positif antara pengungkapan-diri dan kepuasan pernikahan. Kedua, intimasi merupakan variabel yang memediasi hubungan antara pengungkapan-diri dan kepuasan pernikahan.

\section{METODE PENELITIAN}

\section{Subjek}

Subjek pada penelitian ini adalah 110 individu (54 laki-laki dan 56 perempuan) yang sudah menikah, pernikahan pertama, dan setiap subjek hanya memiliki satu orang pasangan (monogami). Sementara lokasi subjek pada penelitian ini adalah Kota Cilegon, Banten.

\section{Metode Pengumpulan Data}

Alat pengumpul data yang digunakan dalam penelitian ini adalah sebuah kuesioner yang terdiri atas tiga skala pengukuran. Pertama, kepuasan pernikahan diukur dengan menggunakan adaptasi Kansas Marital Satisfaction Scale (KMSS) yang dibuat oleh Schumm dkk. (1986). Kedua, intimasi diukur dengan menggunakan adaptasi Personal Assessment of Intimasi in Relationships (PAIR) yang dibuat oleh Schaefer dan Olson (1981). Ketiga, pengungkapan diri diukur dengan menggunakan modifikasi
Marital Self-Disclosure Questionnaire (MSDQ) yang dibuat oleh Waring dkk (1998).

\section{Teknik Analisis Data}

Hipotesis pertama dalam penelitian ini dilakukan dengan teknik analisis korelasional Spearman. Sementara untuk proses pengujian hipotesis kedua dilakukan dengan salah satu teknik dalam pendekatan product of coefficient, yaitu teknik bootstrapping.

Pendekatan product of coefficient bertujuan untuk menguji signifikansi pengaruh tak langsung atau indirect effect (jalur ab). Pendekatan ini dipilih peneliti karena uji signifikansi terhadap koefisien indirect effect ab diakui memberikan pengujian yang lebih langsung terhadap hipotesis mediasional dibanding pendekatan lainnya (Preacher \& Hayes, 2004; Preacher dkk, 2007). Sementara teknik bootstrapping dipilih karena teknik bootstrapping tidak membuat asumsi tentang bentuk distribusi variabel atau distribusi sampling statistik seperti yang terjadi dalam teknik tes Sobel (Preacher \& Hayes, 2004). Hal ini didasarkan pada beberapa temuan yang menunjukkan bahwa pengujian hipotesis mediasi (indirect effect ab) sangat mungkin berdistribusi tidak normal namun menunjukkan proses mediasi (Shrout \& Bolger, 2002; Preacher \& Hayes, 2004). Selain itu, teknik ini juga dipilih karenatidak memerlukan sampel yang besar dalam proses analisisnya.

Perhitungan dalam penelitian ini dilakukan dengan menggunakan bantuan program Software Statistical Product and Service Solution (SPSS) 18 for Windows ditambah dengan macro bootsrapping mediasi sederhana untuk SPSS (Preacher \& Hayes, 2004).

\section{HASIL PENELITIAN}

Hasil analisis terhadap data penelitian yang diperoleh menunjukan koefisien 
korelasi r sebesar 0.176 dengan p 0.03 (< 0.05 ) pada uji satu ekor (tabel 1). Hal ini menunjukan bahwa ada korelasi positif yang signifikan antara pengungkapan-diri dan kepuasan pernikahan. Artinya, semakin tinggi pengungkapan-diri seseorang kepada pasangannya, maka semakin tinggi pula tingkat kepuasan pernikahannya. Dengan demikian, hipotesis pertama yang menyatakan ada hubungan positif antara pengungkapandiri dengan kepuasan pernikahan diterima.

Tabel 1. Correlations

\begin{tabular}{|c|c|c|c|c|}
\hline & & & $\begin{array}{c}\text { Pengungkapan- } \\
\text { dini }\end{array}$ & $\begin{array}{l}\text { Kepuasan } \\
\text { Pemikahan }\end{array}$ \\
\hline \multirow[t]{6}{*}{ Spearman's ino } & \multicolumn{2}{|c|}{ Pengungkapan Correlation Coefficient } & 1.000 & $.176^{\prime}$ \\
\hline & \multirow[t]{2}{*}{ din } & $\operatorname{Sig}(1-t a i l e d)$ & . & .033 \\
\hline & & N & 110 & 110 \\
\hline & \multirow{3}{*}{$\begin{array}{l}\text { Kepuasan } \\
\text { Pemika' }\end{array}$} & Correlation Coefficient & $.176^{\prime}$ & 1.000 \\
\hline & & Sig. (1-tailed) & .033 & \\
\hline & & $\mathrm{N}$ & 110 & 110 \\
\hline
\end{tabular}

Hasil bootstrapping (tabel 2) dengan 1000 sampel menunjukan bahwa indirect effect memiliki koefisien sebesar 0.35 dengan perkiraan signifikansi terletak di antara 0.1812 (batas bawah) dan 0.5532 (batas atas) dengan interval kepercayaan $95 \%$. Karena nol tidak dalam interval kepercayaan $95 \%$, sehingga dapat disimpulkan bahwa efek tidak langsung memang secara signifikan berbeda dari nol pada taraf signifikansi 0.05 (Preacher \& Hayes, 2004). Dengan demikian, hipotesis kedua yang menyatakan bahwa intimasi merupakan mediator antara pengungkapan-diri dengan kepuasan pernikahan diterima.

\section{PEMBAHASAN}

Hasil pengujian hipotesis pertama hasil penelitian ini menunjukkan bahwa terdapat hubungan yang signifikan antara pengungkapan-diri dan kepuasan pernikahan. Semakin tinggi pengungkapan-diri seseorang, semakin meningkat pula kepuasan pernikahannya. Hasil temuan ini menunjukkan tentang pentingnya peran pengungkapan-diri dalam interaksi sosial, atau dalam konteks ini hubungan pernikahan. Dengan pengungkapan-diri, seseorang dapat mengekspresikan perasaannya kepada pasangannya tentang situasi, menyampaikan pikiran dan pendapat tentang suatu topik, mendapatkan kepastian tentang perasaan, atau mendapatkan suatu saran atau nasihat dari orang lain (Baumeister \& Vohs, 2007).

Melalui pengungkapan-diri, seseorang bisa menyampaikan berbagai keluhan maupun keberatannya terhadap suatu hal yang dipandang mengganggu dalam sebuah pernikahan kepada pasangannya. Hal ini akan membantunya dalam melepaskan unek-unek dan ketegangan (tension) dalam dirinya. Selain itu, pengungkapan-diri juga bisa menjadi sarana untuk menceritakan keinginan-keinginan terdalam individu terkait dengan cita-cita pribadi, dan berbagi tentang ekspektasi terkait pasangan ataupun permasalahan rumah tangga. Dengan pengungkapan diri pada akhirnya, pasangan dapat lebih memahami dan memberikan dukungan terhadap dirinya. Sebagaimana yang telah diketahui, dukungan sosial (pasangan) termasuk salah satu faktor yang berpengaruh terhadap kepuasan pernikahan (Mickelson dkk, 2006).

Hipotesis kedua dari penelitian ini berbicara tentang proses mediasi. Model mediasi dalam proses psikologis menjadi populer karena mediasi dapat menjelaskan hubungan variabel yang dapat diurai menjadi komponen-komponen yang mampu mengungkapkan kemungkinan mekanisme sebab-akibat. Model ini berguna untuk pengembangan dan pengujian teori, serta menjadi identifikasi titik kemungkinan intervensi dalam bidang terapan (Shrout \& Bolger, 2002). Secara umum, suatu variabel dikatakan berfungsi sebagai mediator dapat dilihat dari sejauh mana variabel tersebut dapat 
menjelaskan hubungan antara variabel bebas dan variabel tergantung. Dengan kata lain, sebuah mediator menawarkan penjelasan tentang mengapa dan bagaimana suatu efek tertentu (variabel tergantung) dapat muncul (Baron \& Kenny, 1986).

Pada hipotesis kedua, intimasi terbukti menjadi variabel mediator dalam hubungan antara pengungkapan-diri dan kepuasan pernikahan. Berdasarkan hasil yang diperoleh, hubungan antara pengungkapan-diri dan kepuasan pernikahan menjadi lebih kecil dan tidak signifikan setelah mengontrol intimasi. Dalam hal ini, intimasi berperan sebagai mediator penuh dalam hubungan antara pengungkapan-diri dengan kepuasan pernikahan, bukan sebagai mediator parsial (Kenny dkk, 1998). Artinya, ketika seseorang mengungkapkan diri kepada pasangannya, lalu dalam prosesnya tidak memunculkan intimasi, maka akumulasi dari interaksi tersebut tidak akan memunculkan kepuasan pernikahan, bahkan berpotensi menurunkan kepuasan pernikahan. Hal ini dapat dilihat dari hubungan pengungkapan diri dan kepuasan pernikahan yang menjadi negatif setelah mengontrol intimasi.

Sementara itu, analisis tambahan yang dilakukan terhadap data penelitian menunjukkan sebuah temuan menarik. Pertama, hasil korelasi antara pengungkapan-diri dan kepuasan pernikahan berdasarkan jenis kelamin menunjukkan bahwa pengungkapan-diri berkorelasi positif dengan kepuasan pernikahan perempuan, namun tidak pada kepuasan pernikahan laki-laki. Artinya, pengungkapan-diri merupakan salah satu variabel penting yang memberikan kontribusi sebesar $10.9 \%$ kepuasan pernikahan perempuan, namun pengungkapan-diri tidak berkorelasi terhadap kepuasan pernikahan suami. Sementara hasil analisis mediasi berdasarkan jenis kelamin menunjukkan bahwa intimasi merupakan mediator dalam hubungan antara pengungkapandiri dan kepuasan pernikahan, baik pada laki-laki maupun perempuan.

Secara keseluruhan, peneliti mengakui bahwa penelitian ini masih memiliki berbagai kelemahan. Pertama, sampel pada penelitian ini memiliki tingkat kepuasan pernikahan yang sangat tinggi, sehingga tingkat kepuasan pernikahan pada individu yang rendah atau sangat rendah kurang terwakili. Kedua, penelitian ini tidak menyertakan skala social-desirability. Hal ini menjadi penting, karena berdasarkan pengalaman peneliti, topik tentang pernikahan (terutama kekurangan dalam pernikahan) merupakan isu yang sensitif untuk diangkat dan dibicarakan, terlebih kepada orang asing. Hal tersebut berpotensi memunculkan bias pada jawaban yang diberikan subjek penelitian.

\section{SIMPULAN DAN SARAN}

\section{Simpulan}

Simpulan pertama pada penelitian ini adalah kepuasan pernikahan subjek terkait erat dan sejauhmana subjek mampu mengungkapkan diri kepada pasangannya. Kedua, intimasi merupakan mediator penuh yang mampu menjelaskan sekaligus juga menentukan hubungan antara pengungkapan-diri dengan kepuasan pernikahan.

\section{Saran}

Berdasarkan penelitian yang telah dilakukan, terdapat beberapa saran yang dapat diberikan peneliti terkait proses dan hasil dari penelitian ini. Pertama, individu hendaknya meningkatkan kemampuan dan keterampilannya dalam mengungkapkan-diri kepada pasangannya untuk menjaga dan memelihara kepuasan terhadap pernikahan. Karena pengungkapan-diri merupakan perangkat dalam memecah kebekuan dan kebuntuan 
komunikasi.

Kedua, pasangan (lawan bicara) juga sebaiknya ikut terlibat aktif dalam mengungkapkan-diri serta menanggapi dengan baik topik yang dibicarakan oleh individu. Dengan begitu tidak terjadi ketimpangan, atau dengan kata lain pengungkapan-diri didominasi oleh satu pihak saja (tidak imbang). Selain itu, penanggapan yang baik dari pasangan terhadap pembicaraan merupakan persoalan yang tidak kalah penting untuk diperhatikan. Seyogyanya, komunikasi dalam rumah tangga bersifat interaktif dan hangat. Karena dengan iklim komunikasi yang demikianlah intimasi akan terbentuk dengan subur, dan sebagai buahnya, pernikahan akan terasa memuaskan dan membahagiakan.

Ketiga, bagi peneliti yang tertarik dengan topik serupa, penelitian selanjutnya disarankan untuk melibatkan subjek dengan tingkat pengungkapan-diri, intimasi, dan kepuasan pernikahan yang lebih variatif, sehingga hasil penelitian yang diperoleh bisa menggambarkan dengan lebih baik. Selain itu, peneliti selanjutnya hendaknya menyertakan skala social-desirability untuk digunakan dalam instrumen penelitian. Karena dengan menyertakan skala social-desirability, peneliti akan mengetahui apakah hasil penelitian terdapat bias ataukah tidak. Dengan demikian, kepercayaan terhadap hasil penelitian pun akan semakin tinggi. Sejauh pengetahuan peneliti, topik ini merupakan penelitian pertama yang menggunakan analisis mediasi terhadap hubungan pengungkapan-diri, intimasi, dan kepuasan pernikahan. Dengan demikian, hasil penelitian ini membuka peluang kepada peneliti selanjutnya untuk melakukan pengujian dan pembuktian lebih lanjut dengan metode eksperimen dengan melakukan manipulasi terhadap pengungkapan-diri subjek ataupun beserta pasangannya.

\section{DAFTAR PUSTAKA}

Ahmadi, K., Kimiaee, S., \& Afzali, M. H. (2010). Effect of family problemsolving on marital satisfaction. Journal of Applied Sciences, 1-6.

Aron, A. P., Mashek, D. J., \& Aron, E. N. (2008). Closeness as including other in the self. Dalam Mashek, D. J. \& Aron, A., Handbook of closeness and intimacy. New Jersey: Lawrence Erlbaum Associates.

Baron, R. M. \& Kenny, D. A. (1986). The moderator-mediator variable distinction in social psychological research: Conceptual, strategic, and statistical considerations. Journal of Personality and Social Psychology, 51, 1173-1182.

Baumeister, R. F. \& Vohs, K. D. (2007). Encyclopedia of social psychology. California: SAGE Publications.

Bradbury, T. N., Fincham, F. D., \& Beach, S. R. H. (2000). Research on the nature and determinants of marital satisfaction: A decade in review. Journal of Marriage and the Family, 62(4), 964-980.

Busby, M. D., Christensen, C., Crane, D. R., \& Larson, J. H. (1995). A revision of the dyadic adjustment scale for sse with distressed and nondistressed couples: Construct hierarchy and multidimensional scales. Journal of Marital and Family Therapy, 21(3), 289-308.

Chung, H. (1990). Research on the marital relationship: A critical review. Family Science Review, 3(1), 4154. 
Cook, D. (2001). Intimacy in marriage and relationships as a developmental task - A comparison of David Schnarch and Harville Hendrix. http://aphroweb.net/papers/marri age-comparison.htm, 26/05/11.

Downing, V. L. (2008). Attachment style, relationship satisfaction, intimacy, loneliness, gender role beliefs, and the expression of authentic self in romantic realtionship. Disertation: University of Maryland.

Fincham, F. D., \& Beach, S. R. H. (2006). Relationship satisfaction. Dalam Vangelisti, A. L. \& D. Perlman, D., The Cambridge handbook of personal relationships. New York: Cambridge University Press.

Fincham, F. D., \& Beach, S. R. H. (2010). Marriage in the new millennium: A decade in review. Journal of Marriage and Family, 72, 630-649.

Fincham, F. D, Beach, S. R. H., Harold, G. T., \& Osborne, L. N. (1997). Marital satisfaction and depression: Different causal relationships for men and women?. Psychological Science, 8(5), 351-35.

Green, K., Derlega, V. J., \& Mathew, A. (2006). Self-disclosure in personal relationship. Dalam Vangelisti, A. L. \& Perlman, D., The cambridge handbook of personal relationships. New York: Cambridge University Press.

Hall, C. S. \& Lindzey, G. (1993). Psikologi kepribadian 1: Teori- teori psikodinamik (Klinis). Yogyakarta: Penerbit Kanisius.

Hansen, J. E. \& Schuldt, W. J. (1984). Marital self-disclosure and marital satisfaction. Journal of Marriage and Family, 46(4), 923-926.

Harper, J. M., Schaalje, B. G., \& Sandberg, J. G. (2000). Daily hassles, intimacy, and marital quality in later life marriages. The American Journal of Family Therapy. 28(1), 1-18.

Hendrick, S. S. (1981). Self-disclosure and marital satisfaction. Journal of Personality and Social Psychology, 40,980-988.

Hess, J. (2008). Marital satisfaction and parental stress. Thesis: Utah State University.

Impett, E. A., Beals, K. P., \& Peplau, L. A. (2001). Testing the investment model of relationship commitment and stability in a longitudinal study of married couples. Current Psychology, 20(4), 312-326.

Kenny, D. A., Kashy, D. A., \& Bolger, N. (1998). Data analysis in social psychology. Dalam Gilbert, D., Fiske, S., \& Lindzey, G., The handbook of social psychology. Boston: McGraw-Hill.

Kouneski, E. F. \& Olson, D. H. (2008). A practical look at intimacy: ENRICH couple typology. Dalam Mashek, D. J. \& Aron, A., Handbook of closeness and intimacy. New Jersey: Lawrence Erlbaum Associates.

Larson, J. H., Hammond, C. H., \& Harper, J. M. (1998). Perceived equity and 
intimacy in marriage. Journal of Marital and Family Therapy, 24(4), 487-506.

Laurenceau, J-P., Barrett, L. F., \& Pietromonaco, P. R. (1998). Intimacy as an interpersonal process: The importance of selfdisclosure, partner disclosure, and perceived partner responsiveness in interpersonal exchanges. Journal of Personality and Social Psychology, 74(5), 1238-1251.

Laurenceau, J-P., Barrett, L. F., \& Rovine, M. J. (2005). The interpersonal process model of intimacy in marriage: A daily-diary and multilevel modeling approach. Journal of Family Psychology, 19(2), 314-323.

Laurenceau, J-P., Rivera, L. M., Schaffer, A. R., \& Pietromonaco, P. R. $(2004)$. Intimacy as an interpersonal process: Current status and future directions. Dalam Mashek, D. J. \& Aron, A., Handbook of closeness and intimacy. New Jersey: Lawrence Erlbaum Associates.

Mickelson, K. D., Claffey, S. T \& Williams, S. L. (2006). The moderating role of gender and gender role attitudes on the link between spousal support and marital quality. Sex Roles, 55, 73-82.

Ng, K.-M., Loy, J. T.-C., Gudmunson, C. G., \& Cheong, W. (2008). Gender differences in marital and life satisfaction among Chinese Malaysians. Sex Roles, 60, 33-43.

Oluwole, D. A. 2008. Marital satisfaction: connections of self-disclosure, sexual self-efficacy and spirituality among Nigerian women. Pakistan Journal of Social Sciences, 5(5), 464-469.

Preacher, K. J \& Hayes, A. F., (2004). SPSS and SAS procedures for estimating indirect effects in simple mediation models. Behavior Research Methods, Instruments, \& Computers, 36(4), 717-731.

Preacher, K. J., Rucker, D. D \& Hayes, A. F., (2007). Addressing moderated mediation hypotheses: Theory, methods, and prescriptions. Multivariate Behavioral Research,42(1), 185-227.

Proulx, C. M., Helms, H. M., \& Buehler, C. (2007). Marital quality and personal well-being: A metaanalysis. Journal of Marriage and Family, 69, 576-593.

Regan, P. (2011). Close relationships. New York: Rouledge

Reis, H. T. \& Sprecher, S. (2009). Encyclopedia of human relationships. California: SAGE Publications, Inc.

Rodrigues, A. E., Hall, J. H., \& Fincham, F. D. (2006). What predicts divorce and relationship dissolution?. Dalam M. Fine, M. \& J. Harvey, J., Handbook of divorce and relationship dissolution. New Jersey: Erlbaum.

Rotenberg, K. J., Schaut, G. B., \& O'connor, B. P. (1993). The roles of identity development and psychosocial intimacy in marital success. Journal of Social and Clinical Psychology, 12 (2), 198- 
217.

Rusbult, C. E., Martz, J. M. \& Agnew, C. R. (1998). The investment model scale: Measuring commitment level, satisfaction level, quality of alternatives, and investment size. Personal Relationships, 5, 357391.

Sanders, K. M. (2010). Marital satisfaction across the transition to parenthood. Thesis: University of Nebraska.

Saputra, A. (2011). Tingkat perceraian di indonesia meningkat. http://www.detiknews.com $/ \mathrm{read} / 2$ 011/08/04/124446/1696402/10/ti ngkat-perceraian-di-indonesiameningkat, 05/01/12.

Schaefer, M. T., \& Olson, D. H. (1981). Assessing intimacy: The PAIR inventory. Journal of Marital and Family Therapy, 7, 47-60.

Schumm, W. R., Paff-Bergen, L. A., Hatch, R. C., Obiorah, F. C., Copeland, J. M., Meens, L. D., \& Bugaighis, M. A. (1986). Concurrent and discriminant validity of the Kansas Marital Satisfaction Scale. Journal of Marriage and the Family, 48, 381387.

Shrout, P. E., \& Bolger, N. (2002). Mediation in experimental and nonexperimental studies: New procedures and recommendations. Psychological Methods, 7(4), 422445.

Sternberg, R. J. (1997). Construct validation of a triangular love scale. European Journal of Social Psychology, 27, 313-335.
Troy, A. B. (2000). Determining the factors of intimate relationship satisfaction: Interpersonal communication, sexual c ommunication, and communication affect. Colgate University Journal of the Sciences, 32, 221-230.

Van den Broucke, S., Vertommen, H., \& Vandereycken, W. (1995). Construction and validation of a marital intimacy questionnaire. Family Relations, 44(3), 285-290.

Waring, E. M. \& Chelune, G. J. (1983). Marital intimacy and selfdisclosure. Journal of Clinical Psychology, 39(2), 183-190.

Waring, E. M., Holden, R. R., \& Wesley, S. (1998). Development of Marital Self-Discloure Questionnaire (MSDQ). Journal of Clinical Psychology, 54(6), 817-824.

Waring, J. A. (2001). The Marital SelfDisclosure Questionnaire: A validation study. Thesis: The University of British Columbia.

Weiss, R. L. (2005). A critical view of marital satisfaction. Dalam Pinsof, W. M. \& Lebow, J. L., Family psychology: The art of the science. New York: Oxford University Press. 